\title{
Geometric morphometric analysis and taxonomic revision of the Gzhelian (Late Pennsylvanian) conodont Idiognathodus simulator from North America
}

Nicholas J. Hogancamp, James E. Barrick, and Richard E. Strauss

Acta Palaeontologica Polonica 61 (3), 2016: 477-502 doi:http://dx.doi.org/10.4202/app.00198.2015

A new morphometric approach was developed to study morphological variation within P1 elements commonly referred to as Idiognathodus simulator, which was selected to be the biostratigraphic marker for the base of the global Gzhelian Stage (Carboniferous). This new approach combines landmark-based geometric morphometrics with eigen analyses to analyze shape variation within P1 elements of the I. simulator group, and could be used to analyze shape variation in other morphologically similar conodont groups. Specimens analyzed were obtained from three sections of the early Gzhelian Heebner Shale of the Oread cyclothem in the North American Midcontinent region, the cyclothem from which $I$. simulator was originally named. This analysis shows that the I. simulator group comprises a set of at least five species with asymmetrical P1 element pairs, relatively short adcarinal ridges, and a variably developed eccentric groove. Species discrimination is based on the presence of caudal and rostral lobes, character of the adcarinal ridges, and platform shape. The species $I$. simulator is restricted to $\mathrm{P} 1$ elements with a caudal adcarinal ridge that is isolated from the caudal platform margin. Idiognathodus lateralis sp. nov. is erected to include P1 elements with a caudal adcarinal ridge that is not isolated from the caudal platform margin.

Key words: Conodonta, Idiognathodus, morphometrics, Pennsylvanian, Gzhelian, North America, Midcontinent.

Nicholas J. Hogancamp [hogancampnj@gmail.com], Texas Tech University, Lubbock, Texas 79409, USA; current address: Hess Corporation, 1501 McKinney

Street, Houston, Texas 77010, USA. James E. Barrick [jim.barrick@ttu.edu], Department of Geosciences, Texas Tech University, Lubbock, Texas 79409, USA.

Richard E. Straus [Rich.Strauss@ttu.edu], Department of Biological Sciences, Texas Tech University, Lubbock, Texas 79409, USA. 
This is an open-access article distributed under the terms of the Creative Commons

Attribution License (for details please see creativecommons.org), which permits unrestricted use, distribution, and reproduction in any medium, provided the original author and source are credited.

\author{
FoF $F$ Full text $(1,046.4 \mathrm{kB})$ । \\ FoF Supplementary file $(443.5 \mathrm{kB})$
}

